\title{
Hawaii: Pacific Crucible of American Legal History
}

\section{by WiLLIAMSON B.C. CHANG*}

\section{I \\ INTRODUCTION}

Hawaii is America's crucible for legal history. Hawaii's unique experience deserves some place in any consideration of American legal history. Hawaii is a rich source of some of the most interesting controversies in American legal history. These include America's involvement in the overthrow and annexation of the Hawaiian Islands; the development and application of the insular doctrine; Asian exclusion and immigration policy; the imposition of martial law during World War II; the abolition of the death penalty; mandatory health insurance; and the constitutionality of same-sex marriages. Most of all, however, Hawaii is at the cutting edge of "judicial takings" - the constitutional clash between the past and the present.

II

\section{A WATER RIGHTS CASE}

In McBryde Sugar Co. v. Robinson, two sugar companies sought to settle competing claims to ownership of the surface waters of Hawaii's Hanapepe River. Earlier judicial decisions (stretching back to when Hawaii was an independent nation) had established that the surplus waters of the streams and rivers of Hawaii belonged to the owners of the lands on which the streams originated. The trial court applied these precedents to resolve the parties' differences.

On appeal, the Hawaii Supreme Court reversed and held that there was no such thing as private waters-such waters belonged

\footnotetext{
* Professor of Law, University of Hawaii (wbchang@hawaii.edu). A.B., Princeton University; J.D., University of California-Berkeley.
} 
to the sovereign. Thus, as the King's successor, the State was the owner of the disputed waters. ${ }^{1}$

On rehearing, the Court reaffirmed its decision. ${ }^{2}$ However, Justice Levinson dissented. In his view, the majority, by reinterpreting the laws of the Kingdom of Hawaii (1840-93), had taken the companies' property in violation of the U.S. Constitution.

The businesses (joined by the rest of the local sugar industry) appealed to the U.S. Supreme Court. In their petition, they insisted that even if the law they were relying on was, in some theoretical sense, "wrong," it had become binding with the passage of time. The U.S. Supreme Court declined to grant certiorari. ${ }^{3}$.

\section{III THE RIGHT MAN}

McBryde was decided during the tenure of Chief Justice William S. Richardson (1966-82), a meticulous legal historian who was committed to correcting the historical errors in Hawaii's property law. He was able to succeed in this undertaking despite attacks on his jurisprudence. He was the right man, at the right time, with the right instrument. He was also the founder (in 1973) of the University of Hawaii School of Law, an institution that now bears his name and where I have been a faculty member for 37 years.

Richardson imagined the law school as a place where the unique experience of Hawaii, reflected in the legal history of the islands, could be taught, discussed, and debated. ${ }^{4}$ In particular, it would be a place where the proper role of the past, namely Hawaiian custom and tradition, would be studied.

To Richardson, the origins of the judicial takings dispute that arose in McBryde, as well as the uniqueness and complexity of Hawaii's legal history, lie in the fact that Hawaii has had four vastly different political and legal regimes. ${ }^{5}$ Each regime had its own con-

\footnotetext{
${ }^{1} 504$ P.2d 1330 (Haw. 1973).

2517 P.2d 26 (Haw. 1973).

3417 U.S. 962 (1974).

4 See Carol S. Dodo, The Richardson Years: 1966-1982, at 82-108 (1985).

${ }^{5}$ See Robinson v. Ariyoshi, 658 P.2d 287, 306 n.25 (Haw. 1982), reconsideration denied, 726 P.2d 1133 (Haw. 1983) ("The first was the period prior to 1893, during which Hawaii was a constitutional monarchy and the justices of the Supreme Court
} 
stitution, statutes, and common law. The political status of persons often changed during regimes. One who was a loyal citizen during one regime was deemed a rebel during another. Chief Justice Richardson simply refused to accord stare decisis to decisions that were issued when Hawaii was not governed democratically (18931959).

\section{IV OUR LEGAL HISTORY COURSE}

Our legal history course (I teach it with Professor Carl Christensen) has four main tenets. First, Hawaii is the home of "judicial takings." There are three cases in the United States in which federal courts have held that the U.S. Constitution can be violated by state courts that resurrect old law to displace longstanding settled principles of property law-all are from Hawaii.

Thus, in Hawaii, the consequences of legal history are not simply a matter of academic debate. Rather, Hawaii is a crucible where issues raised by the legal history of the islands are front page news. These issues are basic and practical. Where do beaches begin and end? Does the public have access rights over private property? Is it an unconstitutional taking of property without just compensation if the Hawaii Supreme Court overturns supposedly settled law?

The course's second tenet is that those who practice in Hawaii without an understanding of its deeply intricate legal heritage are flying blind. It is impossible to truly understand and appreciate current controversies in Hawaii customary law without an understanding of the deep political, social, and legal forces that have come together to render Hawaii unique.

The third tenet is that the legal history of Hawaii is a two-way street. Developments in Hawaii have had as much bearing on the course of American jurisprudence as developments in America have had on Hawaii's jurisprudence. Hawaii has played a significant role

were appointed by the king. In 1893, the monarchy was overthrown and a republican form of government was substituted. During this period, the justices were appointed by that government. In 1897, Hawaii was annexed by the United States and until 1959 was a territory with our judges and justices appointed by the President of the United States with the advice and consent of the United States Senate. In 1959, Hawaii became a state."). 
in the development of American legal history. For example, Hawaii was the proxy by which the great turn in American political and constitutional law occurred. The global expansion in 1898 (by which the United States took insular territories) meant the United States became an empire-a status and legal system that had been forsworn by those who created the U.S. Constitution.

Fourth, Hawaii has not only influenced American legal history, it has been the test tube for developments in American law. As noted at the outset of this essay, it was among the first states to abolish the death penalty and adopt mandatory health care and the first to judicially recognize same-sex marriages.

\section{V \\ CONCLUSION}

Hawaii, America's only overseas island state, has stretched the United States both geographically and legally. For our law school, that has meant that legal history is more than a mere elective-it is built into our very foundation. 